Invited Review

\title{
Development of Coal Utilization Technologies and Future Tasks in Cokemaking Process
}

\author{
Kenji KATO*1, and Yutaka SuZUKI*2 \\ (Received July 22, 2013) \\ コークス製造プロセスにおける石炭資源利用技術の発展と今後の課題 \\ 加藤健次*1, 鈴木 豊*2
}

Coal is very important resource for producing high quality metallurgical coke. In Japan, improvement of coke quality is strongly demanded to operate large inner volume blast furnaces smoothly. So, effective coal utilization technologies involving new cokemaking process were developed for a long period. Research themes are mainly focused on the expansion of coal resources useable for cokemaking, improving coke productivity and reducing energy consumption. Especially improvement of coke quality is very important, because it generally leads to increase the blending ratio of low grade coals in coal charge without deteriorating coke strength.

In this paper, new cokemaking technologies such as DAPS process and SCOPE21 process are introduced. Understanding of these processes is expected to contribute to further innovative development of new cokemaking process.

石炭は, 高炉用コークス製造原料として重要な資源である。日本では, 大型高炉を安定的に操業するために, 高強度のコークスを製造する技術開発が求められている。このため，石炭資源を有効に利用して，高品質の コークスを製造するための新コークス製造プロセスの開発が長い間行われてきた。課題として, コークス製造 用原料として使用可能な石炭資源範囲の拡大, コークスの生産性向上, 省エネルギーに重点を置いた研究開発 が実施されてきた。コークス品質を向上させる技術が開発できれば, コークス製造用原料して低品位な石炭の 使用比率を上昇させても，コークス強度の低下を抑制することが可能となる。

本論文では，コークス製造技術開発の中でも特徴のある石炭事前処理技術として，DAPSプロセスおよび SCOPE21プロセスを紹介する。これらの新コークス製造技術の開発内容が, 今後の革新的な技術開発の一助に なれば幸いである。

\section{Key Words}

Coal, Coke, DAPS process, SCOPE21

1.はじめに

わが国の鉄鋼業で使用される総エネルギーのうち，石 炭系は約 $86 \%$ を占めており，重要なエネルギー源であ る1)。製鉄用コークスは，高炉において鉄鉱石を還元する

* 1 Engineering $\mathrm{R} \& \mathrm{D}$ Institute \#2, Nippon Steel \& Sumikin Engineering Co., Ltd. 10-12, Koyocho, Wakamatsu-ku, Kitakyushu-city, Fukuoka 808-0002, Japan

* 2 Ironmaking Technology Div., Nippon Steel \& Sumitomo Metal Corporation. 6-1 Marunouchi, 2-Chome, Chiyoda-ku, Tokyo 100-8071, Japan
際の還元材として使用される。わが国では，1年間に約 6 千万トンの石炭を原料として，約 3 千 2 百万トンの コークスが製造されている2)。コークス製造時の副産物と して，コークス炬ガス抽びタール，軽油などの油分が

* 1 （元）新日鐵住金(株)

(現) 新日鉄住金エンジニアリング(株) 技術開発第二研 究所

干 808-0002 福岡県北九州市若松区向洋町 10-12

*2 新日鐵住金(株) 製銑技術部

₹ 100-8071 東京都千代田区丸の内 2-6-1 
製造される。コークス炬ガスは，脱硫，脱アンモニアな どの処理を行った後に，クリーンなガスとして製鉄所内 の加熱設備および発電所などの燃料として使用される。 タール, 軽油などの油分は化学原料として, 全量有効に 使用される。

近年，コークス製造用の石炭（原料炭）の価格が大幅 に上昇している。さらに，長期的な視点からみると，粘 結性の高い良質原料炭の資源賦存量は少ないため，良質 な石炭は今後枯渴傾向である。そのため，低品位な石炭 資源の高度利用技術開発が盛んに行われており, 研究開 発成果の早期実機化に対する期待が大きい。

このような背景を踏まえて,わが国の鉄鋼業における 石炭資源の有効利用技術の開発抒よび将来の開発課題に ついて述べる。

\section{2. 高炉におけるコークスの役割とコークス使用比率の} 推移

高炉法による製鉄プロセスの概要を Fig. 1 に示す。鉄 鉱石（焼結鉱）とコークスは高炉の炉頂部から層状に装 入される。炉頂から装入された原料が高炉内を降下する にしたがって向流する高温ガスによって加熱され，直接 あるいは間接に還元反応が進行して溶銑とスラグに分離 され，銑鉄が生産される。高炉内で鉄鉱石を還元するた めにコークスが果たす主な役割は，(1)還元材，(2)熱源，(3) 通気性・通液性維持材の 3 つがある (Fig. 2)。

Fig. 3 に，高炬に打けるコークス，重油㧍よび微粉炭 (Pulverized Coal Injection: PCI) の使用比率の推移を示す。 1960年代より，高炉羽口からの重油などの燃料吹込み技 術が開始され，低還元材比操業が志向されてきた。しか し，重油吹込み技術は，1970年代に起こった 2 度の石油 危機（オイルショック）以降は価格競争力を失い，1982 年以降はわが国のすべての高炉において，重油などを使 用しないオイルレス操業に移行した。この後, 高炉操業 では微粉炭吹込み（PCI）技術の開発が盛んに行われた。 1981 年 6 月に新日鐵住金(株) 大分製鐵所第 1 高炬に微粉 炭吹达み設備が導入されて以降，わが国の各社の高炉で

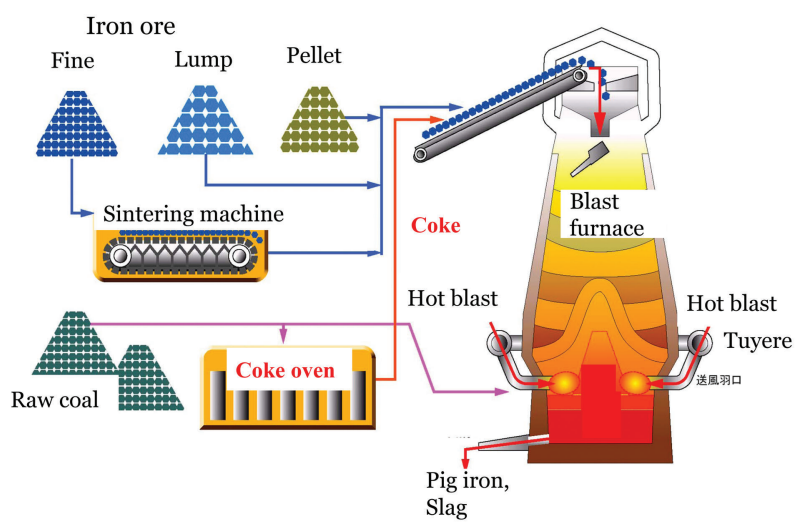

Fig. 1 Ironmaking process flow

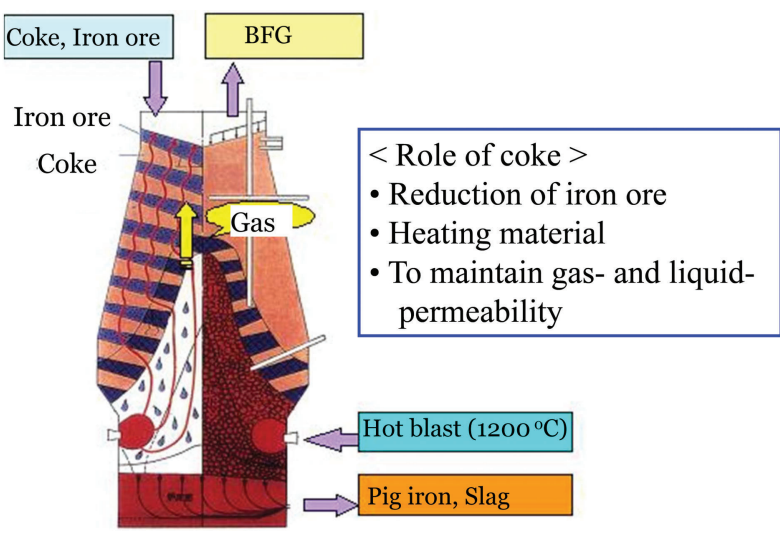

Fig. 2 Role of coke on Blast Furnace operation

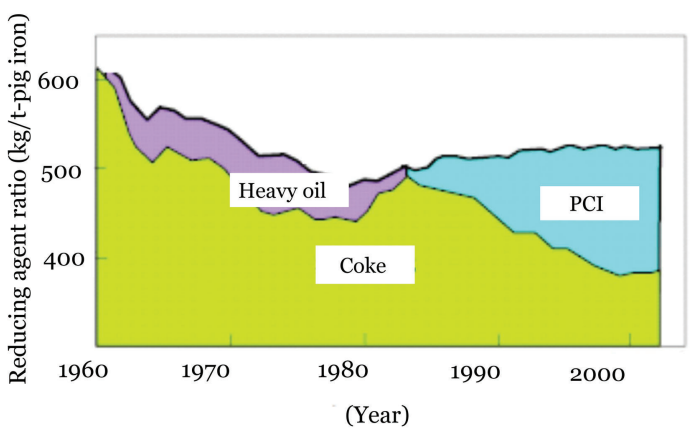

Fig. 3 Trend of average reducing agent ratio for the Blast Furnaces in Japan

PCI設備が急速に普及した ${ }^{3)}$ 。1988年には国内の全高炉に PCI設備が設置され，銑鉄 1 トンの製造に対する微粉炭の 平均使用量は $130 \mathrm{~kg} / \mathrm{t}$ に達した。1998年には神戸製鋼所 加古川第 1 高炉で $254 \mathrm{~kg} / \mathrm{t}^{4}$ )，JFE福山第3高炉で $266 \mathrm{~kg} /$ t5) 6) のように多量の PCI 使用試験が実施された。PCI 比 率を上昇させて高炉を安定的に操業するためには，焼結 鉱に対するコークス比率が低下した条件下で，高炉内で 焼結鉱が還元される融着帯における通気性を十分に確保 することが重要である。また，わが国の高炉は生産性向 上を目的として大型化が進められてきており, 内容積が $5000 \mathrm{~m}^{3}$ 以上の大型高炉が 13 基稼働している ${ }^{7) 。 こ の よ ~}$ うな大型高炉で鉄鉱石の還元反応を効率よく安定的に行 う還元材として, 高炉内で必要な還元材, 熱源, 通通気 性・通液性維持材としての役割を同時に果たし得る安価 で堅牢な炭素材料はコークスの他にない。このため,コー クスは近年益々重要視されている。

\section{3. コークス製造技術における石炭有効利用技術の開発} 状況

西岡は, 石炭がコークスに変化する過程の物理的, 化 学的変化を以下のように解説した8)。石炭の化学的変化と しては, 約 $400^{\circ} \mathrm{C}$ から揮発分の放出が始まる。冷却されて タールになる成分と気体で放出されるメタン, エタンな どの炭化水素が揮発し，さらに温度が上昇すると水素が 
多く揮発する。一方，物理变化としては約 $100^{\circ} \mathrm{C}$ での脱水 に始まり，揮発分が多く発生する約 $400^{\circ} \mathrm{C}$ から石炭の膨張 が始まる。さらに温度が上昇すると収縮が始まり，約 $1000^{\circ} \mathrm{C}$ まで乾留するとコークスが生成する。

室炉式コークス製造プロセスの概要を Fig. 4 に示す9)。 室炉式コークス炉で石炭を乾留して製造されるコークス は，約 $45 \sim 50 \%$ の気孔率を有する多孔性炭素材料であ る。コークス炬は炭化室と燃焼室がサンドイッチ状に交 互に連なっている（Fig. 5)。高品質なコークスを製造す るためには, 石炭の選択と配合, 粉砕処理, 乾燥処理な どの事前処理技術が重要である 10111。 わが国のコークス 製造技術では，長い間，石炭配合技術の研究が重点課題 とされてきた。例えば，城は石炭配合理論について，石 炭の粘結成分（粘結性の指標）と石炭の繊維質成分の強 度（石炭化度に相当する指標）を用いて検討し，Fig. 6を 提案した ${ }^{12)}$ 。Fig. 6は，石炭の繊維質部分と粘結成分のバ ランスを示した図であり，粘結成分と繊維質部分の均衡 を取ることにより，繊維質部分由来のコークス組織が緻 密になり，コークス強度が向上することを示唆している。 石炭配合理論の研究は, 今後の低品位な石炭利用技術を 検討する上で，益々重要な課題である。

各種の事前処理設備で処理された石炭は，コークス炉 の炭化室に装入されて，約 $1100 \sim 1200^{\circ} \mathrm{C}$ に加熱された 両側の棟瓦壁を介して間接的に加熱され，還元雾囲気条

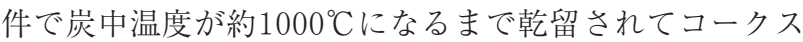
となる。高炉用コークスの原料として使用可能な石炭は 粘結炭が中心であるが，世界の石炭資源のうち 7 割以上

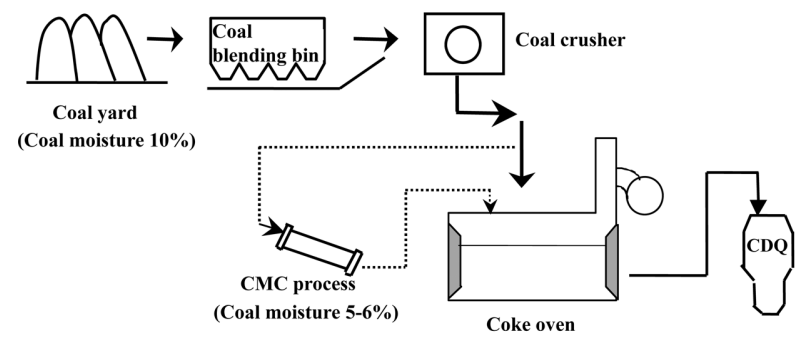

Fig. 4 Conventional cokemaking process flow

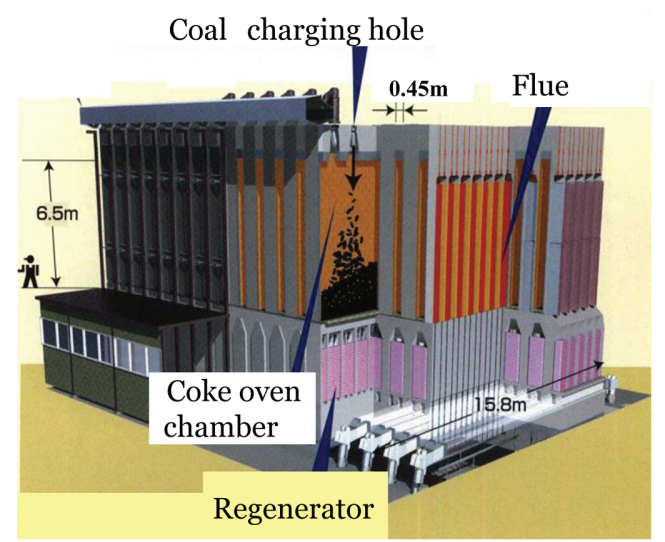

Fig. 5 Appearance of coke oven battery

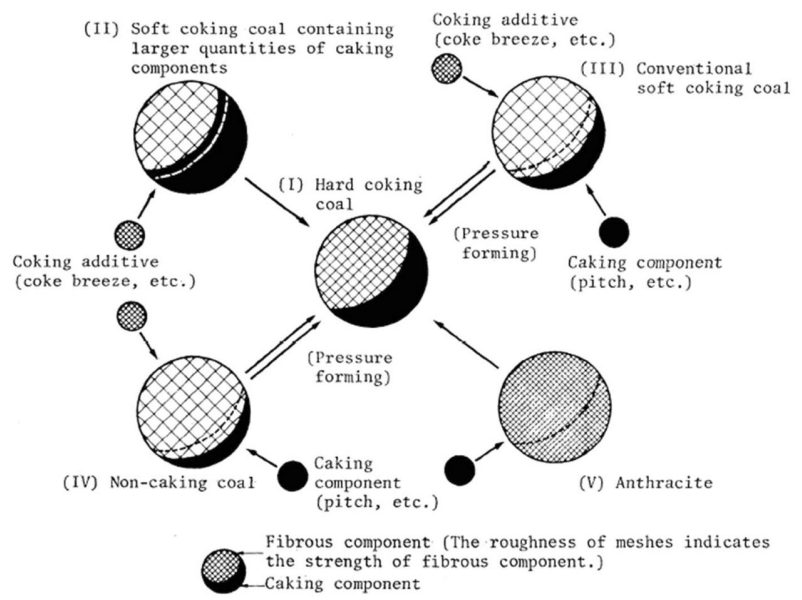

Fig. 6 Relationship among the coke strength, the amount of caking component and the strength of fibrous component

は粘結性の低い劣質な石炭である。そこで，劣質な石炭 を多量に使用する条件で強度の高いコークスを製造する 技術開発が重要な課題である。わが国では石炭事前処理 設備の開発が盛んに行われており，世界でも類をみない 石炭乾燥技術が実機化されている ${ }^{13)}{ }^{14)}$ 。

最初に開発された石炭乾燥技術は, CMC (Coal Moisture Control）プロセスである。コークス製造用に使用する石 炭は海外から輸入されて抢り，水分を約 $10 \%$ 程度含んで いる。CMCプロセスの発想は，石炭の水分を低下させる ことにより，コークス炉に装入する石炭の嵩密度を上昇 させて，コークス強度を向上させるものである。具体的 には，回転式の加熱機を用いて石炭の水分を約 5 ～ 6 \% の範囲に乾燥する。CMCプロセスは1983年に新日鐵住金 (株)大分製鐵所で第 1 号機が稼働開始された ${ }^{15)}$ 。理論的 には，石炭水分を $5 \%$ レベルょりも低下させた方が石炭 の装入密度が上昇するので，コークス強度は向上する。し かし, 石炭水分を $5 \%$ 未満まで乾燥すると, 石炭を乾燥 機からコークス炬まで輸送する途中のベルトコンベアー やコークス炉周辺で微粉炭に起因する発塵量が大幅に増 加し, 環境が悪化する。また, 微粉炭量の増加に伴って コークス炉内の炉壁に付着するカーボン量が増加するた め，コークス炉の炭化室からコークスを押し出す際の押 し出し負荷が上昇し，コークス炉の安定操業が不可能と なる。

そこで，石炭水分をCMCプロセスよりも低下させるた めに, 微粉炭の発塵による環境問題㧍よびカーボン付着 によるコークス押し出し負荷の問題を解決する対策を検 討するとともに，コークス強度をさらに向上させるため の研究開発が行われた ${ }^{16)}{ }^{17)}$ 。石炭乾燥時の発塵量増加の メカニズムを調べた結果，水分が高い場合は石炭中の粗 粒炭に微粉炭が付着しており，水を結合材とするファン デルワールスカにより擬似粒子が生成されているため, 発塵量が少ないことがわかった ${ }^{18)}$ 。石炭を水分 $5 \%$ 未満 
まで乾燥すると, 擬似粒子が崩壊して微粉炭の単粒子化 が起こるために発塵量が増加する。このため, 石炭の発 塵量を増加させないためには, 石炭水分を約 $2 \%$ レ゙゙ル まで乾燥して石炭の擬似粒子を完全に崩壊させた後に, 微粉炭を分離して塊成化する必要があることがわかった。

さらに，石炭に含まれる微細組織成分と石炭粒度の関 係について研究が行われた。石炭の微細組織成分のうち, 粘結性の高いビトリニットは柔らかく，粉砕されやすい 特性を有している。顕微鏡を用いて石炭の微細組織を調 ベた結果，微粉炭中には粘結性が高いビトリニットが濃 縮されていることがわかった。そこで，微粉炭を塊成化 した場合の粘結性を調べた結果，微粉炭を塊成化して嵪 密度を上昇させることにより，Fig. 7に示すように粘結性 が大幅に向上することがわかった ${ }^{19)}$ 。

これらの基礎研究成果を基に，微粉炭を加圧成型して 塊成化することにより微粉炭の粘結性を向上させてコー クス強度を向上させるとともに，乾燥炭の発塵を抑制す る実機プロセスの開発が行われた。このプロセスを確立 するためには，多量の石炭を乾燥しながら微粉炭を分級 する装置の開発が必要であった。そこで，流動層による 乾燥分級設備の開発が行われ，その結果，世界で初めて， Fig. 8に示す約 6800 t/d規模の大型装置によりコークス製

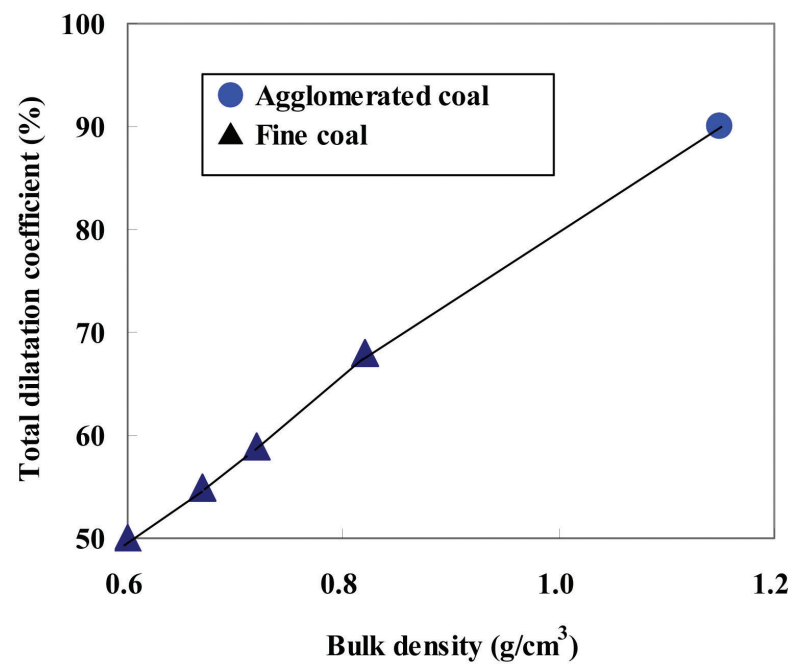

Fig. 7 Relationship between total dilatation coefficient and bulk density

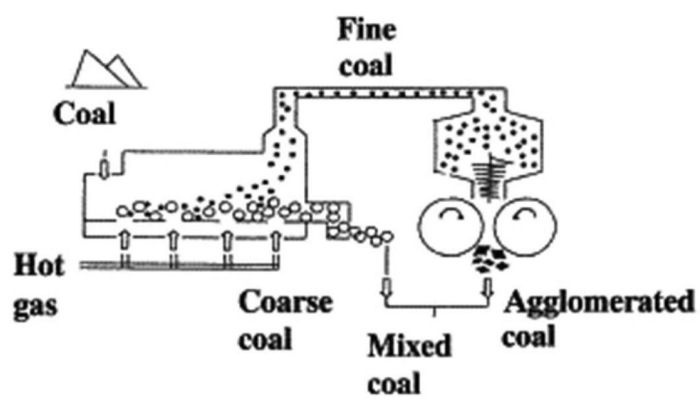

Fig. 8 Process flow of DAPS process

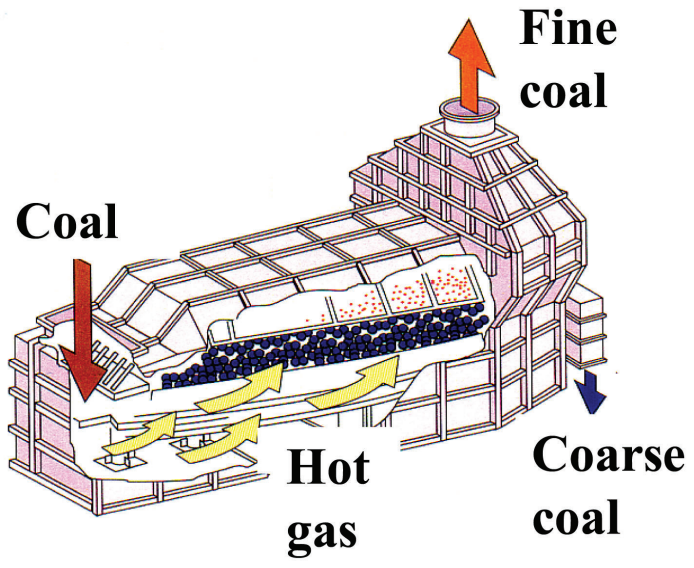

Fig. 9 Fluidized bed dryer

造用の原料炭を効率よく乾燥・分級する設備が開発され た（Fig. 9）16）17)。

このプロセスは DAPS（Dry-cleaned and Agglomerated Precompaction System) と命名され，1992年に新日鐵住金 (株) 大分製鐵所で実機化された。コークス強度が同一の 条件で非微粘結炭の使用比率を比べると，DAPSプロセス

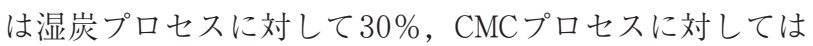
$20 \%$ 多く使用できる優位性がある 16) 17)。

以上のように，CMC プロセスおよび DAPS プロセスは 石炭資源の有效利用技術を開発することを目的として， 石炭粒子の性状およびハンドリング性を改善しながら， コークス品質を向上させる技術開発に取り組んだ成果と して実機化された設備である。

\section{SCOPE21 技術の開発と実機化}

\subsection{SCOPE21 プロセスの開発課題}

わが国で現在稼働中のコークス炉は合計で48炉団ある が，そのほとんどは昭和 40 年代の高度経済成長期に集中 的に建設されており，コークス炉の稼働年数は平均で約 37年を経過している。このため, 日本のコークス炉のほ とんどは 21 世紀初頭に老朽更新時期を迎える。そこで, コークス炉のリプレース（新コークス炉の建設）に向け て, 次世代コークス製造プロセス開発が進められてきた。 現在のコークス製造プロセスは，原料炭として粘結炭を 多量に使用しなければならないという石炭資源制約があ ること, コークスの生産性が低いこと, エネルギー多量 消費構造であること，環境対応力が低い（NOx 規制への 対応が必要）など，解決すべき問題点が多い。コークス 炉のリプレースを行うタイミングは，現状抱えるコーク ス製造上の問題点を解決する絶好の機会である。新コー クス製造プロセス開発を行う上での課題は，わが国の鉄 鋼業界でコークス製造を行うすべての企業にとって共通 な課題である。コークス炬の建設費は，1炉団（コーク ス生産能力 100 万 $\mathrm{t} / \mathrm{y})$ 当たり数百億円規模の投資が必要 
であり，実機規模のパイロットプラント試験を行うため には約 100 億円規模の研究開発費と多くの研究者による 研究体制の構築が必要である。これらの背景を踏まえて, 日本鉄鋼連盟に参加するコークス製造に関する企業によ る国家プロジェクトとして共同で研究開発を実施するこ とが決定され，1994年から2003年にかけて次世代コーク ス製造技術の開発が行われた。本プロジェクトは，スコー プ 21 (SCOPE21 ; Super Coke Oven for Productivity and Environmental enhancement toward the 21st century) と 呼ばれている20)21)。

このプロジェクトでは，以下の 4 点を目標として，新 コークス製造プロセスの研究開発が進められた。

(1)コークス製造用原料として，従来は多量に使用するこ とが不可能であった低品位炭（非微粘結炭）の使用比 率を従来の $20 \%$ から $50 \%$ まで上昇させることにより， 使用可能な石炭資源の炭種を拡大する。

(2)コークスの生産性を向上させる。すなわち, コークス

の乾留時間を短縮させてコークスを製造することに よって，同一のコークス生産量の場合はコークス炉の 窯数を減少させ，コークス炉をコンパクト化する。 (3)コークス製造工程の省エネルギー化を図る。

(4)環境問題対策として, NOx の低減を図る。

SCOPE21 プロセスの開発スケジュールをTable 1 に示 す22２3)。1994 年から 1997 年にかけて基盤技術研究が行 われ，1996年から 1999年にかけて要素技術研究 (ベンチ プラント試験)，1999年から 2003 年にパイロットプラン 卜研究が実施された。さらに，2004年からは実機化が進 められた ${ }^{24)}$ 。

SCOPE21プロセスでは，抜本的に室炉式コークス製造 プロセスの生産性を極限まで向上させる方法を検討した。

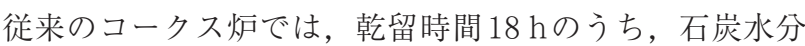
の乾燥だけで $8 \sim 10 \mathrm{~h}$ 程度を要している。コークス炉に 装入する前の石炭事前処理工程で水分の乾燥 ・加熱を急 速に行えば，コークス炉での乾留時間を短縮でき，全体

Table 1 R\&D Schedule of SCOPE21 project

(Fiscal year)

\begin{tabular}{|c|c|c|c|c|c|c|c|c|c|}
\hline 1994 & 1995 & 1996 & 1997 & 1998 & 1999 & 2000 & 2001 & 2002 & 2003 \\
\hline \multicolumn{2}{|c|}{$\begin{array}{l}\text { Basic } \\
\text { research }\end{array}$} & & & & & & & & \\
\hline & & \multicolumn{4}{|c|}{ Bench scale test } & & & & \\
\hline & & & & & \multicolumn{5}{|c|}{ Pilot plant test } \\
\hline & & & & & & & & $\begin{array}{l}\underset{\text { Test }}{\longleftrightarrow} \\
\text { opera }\end{array}$ & tion \\
\hline
\end{tabular}

としての生産性を大幅に向上できる可能性がある。この 発想から，本開発では，コークス炉の事前処理工程とし て石炭の急速加熱技術を検討した。その検討過程で，急 速加熱により石炭が改質されることが発見され，その効 果で劣質な低品位炭 (非微粘結炭)の使用比率を大幅に上 昇させる可能性のあるプロセスとして開発が進められた。

\subsection{SCOPE21 プロセスの特徵}

Fig. 10 にSCOPE21 のプロセスフローを示す23)。コー クス製造用に使用される石炭を流動床乾燥分級機によって 乾燥分級した後に，粗粒炭と微粉炭を別々に $330 \sim 380^{\circ} \mathrm{C}$ まで急速加熱する。微粉炭は熱間成型機を用いて加圧成 型した後に粗粒炭と混合する。このような石炭の事前処 理技術によって，コークス用原料として適さない低品位 炭 (非微粘結炭) の使用比率を大幅に上昇させることを 可能とするとともに，コークスの生産性を大幅に向上さ せて省エネルギーを図る。次に，高温に加熱した石炭を 乾留することにより，炭化室内でのコークス乾留に必要 な時間を短縮し，生産性を大幅に向上させる。

以上の基本コンセプトから構成された新しいコークス 製造技術を開発することによって，Fig. 11に示すように， コークスの乾留時間を大幅に短縮させて, 従来のコーク ス製造プロセスをコンパクト化し，高効率のコークス製 造プロセスを実現することを目標としている ${ }^{23) 。 ~}$

Fig. 12にSCOPE21プロセスにおけるコークス品質向上

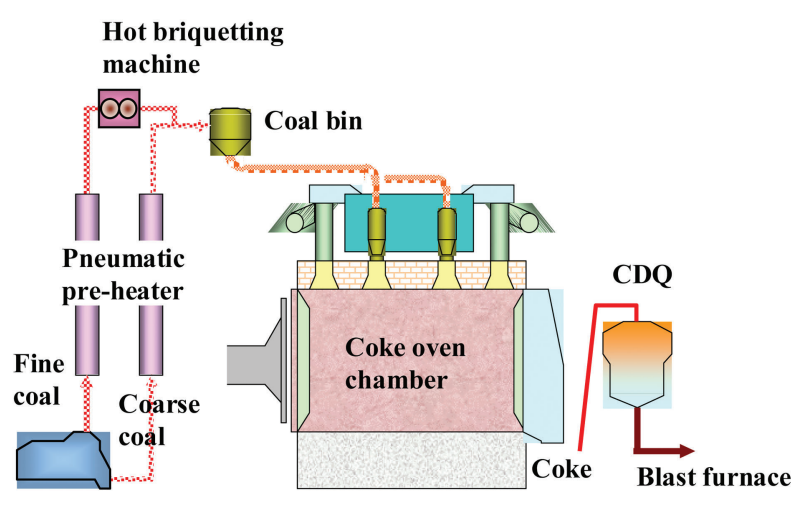

Fluidized bed dryer

Fig. 10 Schematic diagram of SCOPE21 process

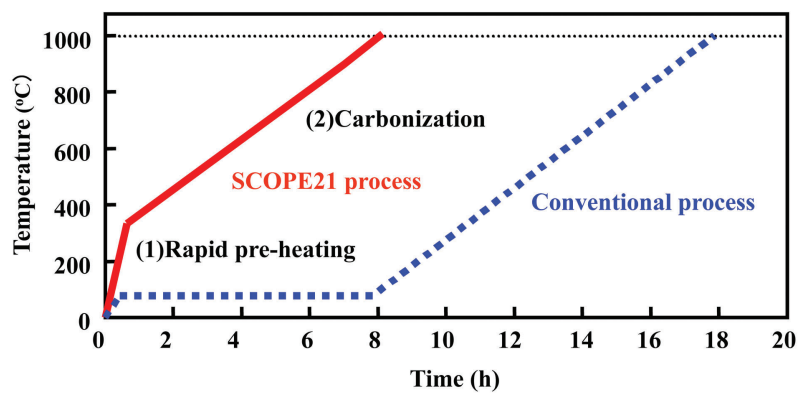

Fig. 11 Comparison of coking time between SCOPE21 and conventional process 


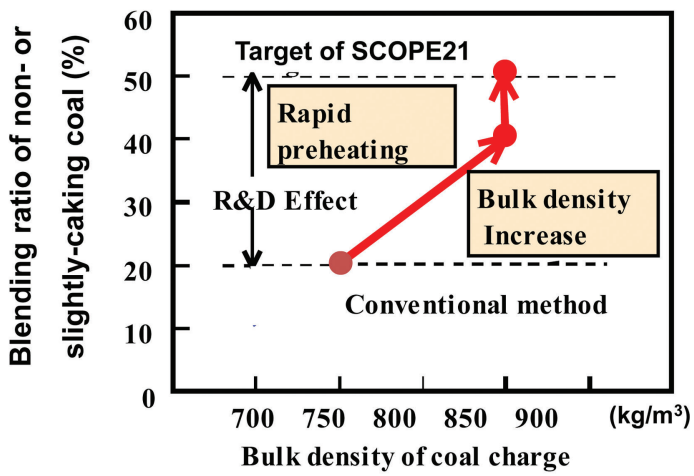

Fig. 12 Technologies for improving coke quality

技術の概要を示す22)。事前処理工程で石炭水分を0\%まで 乾燥，加熱することおよび微粉炭を高密度に塊成化する ことによって，コークス炉の炭化室に装入する石炭の嵪 密度がCMCプロセスにと比較して $750 \mathrm{~kg} / \mathrm{m}^{3}$ から $850 \mathrm{~kg} /$ $\mathrm{m}^{3}$ まで上昇する。さらに，石炭を急速加熱することに よって石炭を改質して軟化溶融性を向上させることに よってコークス化性が向上する。すなわち，SCOPE21で は，石炭の装入密度上昇および石炭改質の効果によって， コークス強度を向上させる2225)。コークス強度向上分は, 低品位の非微粘結炭の使用比率を上昇させても高炉用コー クスとしての所定の強度を維持することができる。

\section{3 設備技術開発}

SCOPE21 プロセスは，石炭を $330 \sim 380^{\circ} \mathrm{C} に$ 急速加熱 することを基本として構築された。急速加熱の実現のた め, 石炭加熱装置として, 気流塔加熱機の採用が考えら れた。気流塔加熱機では高温の加熱ガスと石炭が並流で 接触する。石炭は伝熱が遅く，また粒度分布をもってお り，粗粒は徐々に昇温するが，微粉は比較的速やかにガ ス温度まで昇温するので，加熱条件によっては $380^{\circ} \mathrm{C}$ 以上 に過加熱されて, 品質劣化や粘着卜ラブルを招く恐れが ある。そこで，本プロセスでは，気流塔加熱機の前段に 流動床乾燥分級機を設置し，石炭を $250^{\circ} \mathrm{C}$ 程度まで乾燥・ 予熱することにより気流塔加熱機の負荷を低減するとと もに，加熱に時間を要する粗粒炭と比較的加熱の容易な 微粉炭に分級し，それぞれ別個に気流塔加熱機で急速加 熱する方式を採用した。流動床乾燥分級機および気流塔 加熱機等の石炭事前処理設備については，ラボスケール からパイロットプラントまで，段階を踏んで開発を進め た。試験装置を用いて技術検討とエンジニアリングデー 夕採取を推進するとともに，ソフトシミュレーターの開 発も同時に進めた。流動床乾燥分級機で加熱，分級され た石炭は，気流塔加熱機を使用して，約 $330 \sim 380^{\circ} \mathrm{C}$ まで 急速加熱処理される。

石炭は約 $400^{\circ} \mathrm{C}$ 以上では熱分解し，粘結成分が散冕する ため石炭の軟化溶融性が低下し，コークス強度が低下す
る。このため, 気流塔加熱機における石炭加熱時の温度 制御は非常に重要である。気流塔加熱機に求められる機 能は，流動床乾燥分級機によって約 $200 \sim 250^{\circ} \mathrm{C}$ に予熱さ れた石炭を約 $330 \sim 380^{\circ} \mathrm{C}$ まで均一に急速加熱すること である。さらに, 気流塔加熱機の内部で石炭を落炭させ ないように，加熱ガス流速を設定する必要がある。

パイロットプラントの気流塔加熱機の主仕様は, 石炭 処理量 $(6 \mathrm{t} / \mathrm{h})$ を考慮して, 内径 $770 \mathrm{~mm}$, 高さ $25 \mathrm{~m}$ に 設計された。気流塔加熱機内部で石炭を落炭させないた めに，気流塔加熱機下部の加熱ガス入口に整流板および 分散板を設置し，ガス流速分布の調整を可能とした。パ イロットプラントの気流塔加熱機の運転条件を検討する ために，気流塔加熱機内におけるガス流速分布計算およ び伝熱計算による石炭の加熱特性を評価するためのソフ

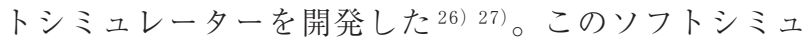
レーターを用いて, 粗粒炭および微粉炭を各々適正な温 度範囲まで急速加熱処理し, 過加熱を防止するための加 熱ガス温度およびガス流量条件を計算した。伝熱計算によ り気流塔加熱機の出側における石炭温度を推算した結果, 各粒度分布の石炭は目標とする温度範囲 $\left(330 \sim 380^{\circ} \mathrm{C}\right)$ まで加熱されることがわかった。このように，粒度分布 を有する石炭粒子を過加熱することなく目標の温度範囲 内に加熱できる技術が開発された。

\section{4 パイロットプラント操業試験}

石炭事前処理〜乾留炉の一貫した設備機能を有するパイ ロットプラントが新日鐵住金 (株) 名古屋製鐵所の構内に 建設され，2002年 3 月から 2003年 3 月まで操業試験が行 われた。パイロットプラントのプロセスフローをFig. 13 に示す。パイロットプラントの石炭事前処理設備は, 石 炭処理量が $6 \mathrm{t} / \mathrm{h}$ で，実機設備の $1 / 20$ のスケールである。 乾留炉は 1 窯で，コークス炉の炉長は実機の $1 / 2$ の $8 \mathrm{~m}$, 炉幅は実機と同じ寸法の $450 \mathrm{~mm}$ ，炉高は $7.5 \mathrm{~m}$ で実機同 等の寸法の設備である。パイロットプラント試験操業は, 低炉温条件で設定した第 1 次操業 (炉温; $1100 \sim 1150^{\circ} \mathrm{C}$ ) と高炉温条件の第 2 次操業 (炉温； $1200 \sim 1280^{\circ} \mathrm{C}$ ) の 2 段階に分けて, 約 1 年間実施された。コークスの乾留試 験は合計で 440 回実施された ${ }^{28)}$ 。

パイロットプラントによる一貫したコークス製造の操 業試験の結果，石炭を高温に急速加熱処理することによ りコークス強度 $\left(\mathrm{DI}^{150}{ }_{15}\right)$ が向上し，非微粘結炭を $50 \%$ 使 用しても強度の高い高炉用コークスを製造できることお よび生産性の高いコークス製造プロセスの実施が可能で あることが確認された ${ }^{28)}$ 。また, 燃焼試験炉等での検討 により新たに開発された低 NOx 燃焼構造が採用され，排 ガス中の NOx 濃度 $100 \mathrm{ppm}$ 以下という目標を達成するこ とが確認された。

パイロットプラント試験までの研究開発段階で取り組 


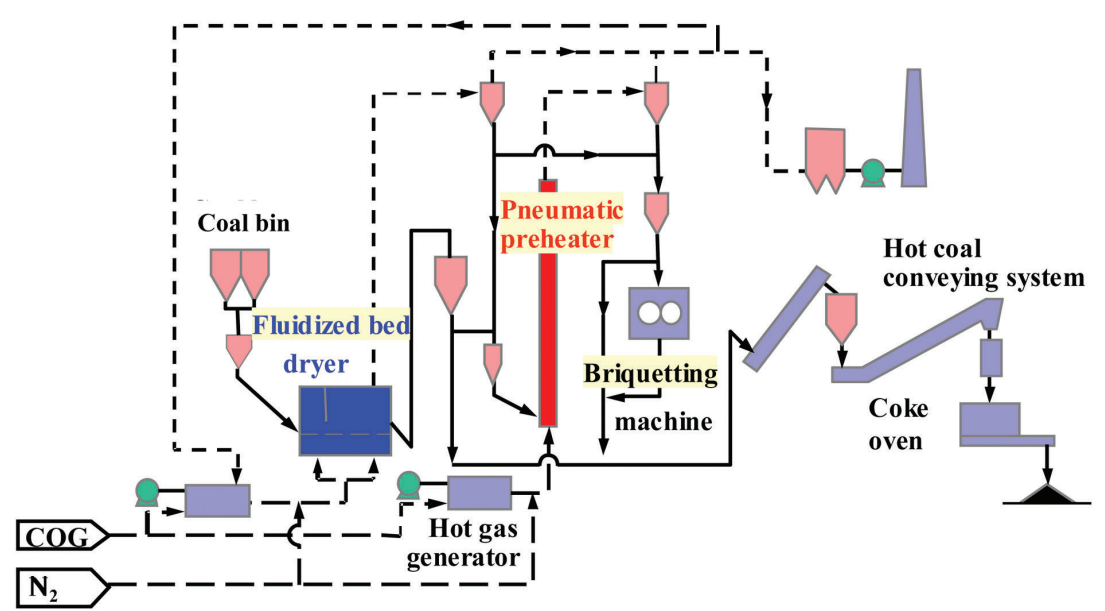

Fig. 13 Process flow of SCOPE21 pilot plant

まれた主な新技術の開発成果は，以下のとおりである。

(1)石炭資源有効利用技術

従来のコークス製造方法では，粘結性が低い非微粘結 炭を多量に使用すると，コークス強度が低下する。その ため，従来のコークス炉では約 $20 \%$ 程度しか非微粘結炭 を使用できなかった。これに対して，SCOPE21プロセス では石炭を $330 \sim 380^{\circ} \mathrm{C}$ に急速加熱処理することにより 石炭の粘結性が向上し，コークス化性が向上する。また， 原料炭中の微粉炭を塊成化することにより，嵩密度が上 昇し，コークス化性が向上する。

これらの効果により，非微粘結炭を50\%使用した場合 でも強度が高いコークスの製造が可能である。本技術の 適用により，コークス製造用原料炭中の非微粘結炭の使 用比率を $50 \%$ まで高められる見通しを得た。

(2)コークス生産性向上技術

事前処理工程で石炭を急速加熱処理した高温炭をコー クス炉炭化室に装入することにより，コークス製造時間 の短縮が可能となり，生産性が大幅に向上する見通しを 得た。

(3)環境対応技術

新たに開発された低 NOx 燃焼構造により，コークス炉 の最高炬温においても燃焼排ガス中 NOx 濃度を従来と比 較して飛躍的に低下できることが確認された。

\subsection{SCOPE21型新コークス炉の建設および稼動状況}

国家プロジェクトの研究開発成果を受けて, SCOPE21 型の新コークス炉の第 1 号機が新日製住金(株)大分製鐵 所構内に建設された ${ }^{24)}$ 。大分第 5 コークス炉の建設工程 の概要をTable 2 に示す ${ }^{24)}$ 。2006 年 4 月～2008年 4 月に かけてコークス炉の建設工事が行われた。コークス炉本 体の建設工事は2008年 1 月に完了し，2008年 2 月 1 日に コークス炬に石炭が初めて装入され，翌日，コークスの 初窯出しが行われた。その後, 石炭事前処理設備, コー クス炉，改質チャンバー（CDQ；Coke Dry Quenching）全
系による総合運転が行われ，2008年 5 月に竣工した。大 分第 5 コークス炉の設備フローをFig. 14に, 主な設備仕 様を Table 3 に各々示す24)。コークス生産能力は 100 万 t/年であり，石炭を装入して乾留する炭化室は 64 門であ り, 従来型で同一の生産量のコークス炉と比べて, 非常 にコンパクト化されている。

現在，大分製鐵所の新コークスプロセスは石炭配合と して非微粘結炭比率50\%以上使用した条件で，高強度の コークスを安定的に製造しており，順調な操業を継続中 である。大分第 5 コークス炉における 1 年間のエネル ギー削減量を評価した結果，コークス生産量 100 万 $\mathrm{t} /$ 年 時の 1 年間の重油使用量の削減量は 9.43 万 $\mathrm{kl}$ に相当する。 これは, $\mathrm{CO}_{2}$ 排出量では 1 年間に 25.6 万 $\mathrm{t}$ の $\mathrm{CO}_{2}$ 削減に相 当する ${ }^{24)}$. SCOPE21の第 2 号機は新日鐵住金(株) 名古屋 製鐵所に建設され，2013 年 6 月に竣工した ${ }^{29)}$ 。

Table 2 Construction schedule of Oita No. 5 coke oven battery (Fiscal year)

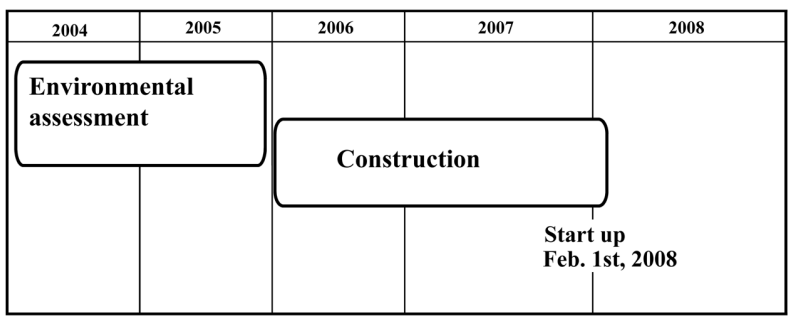

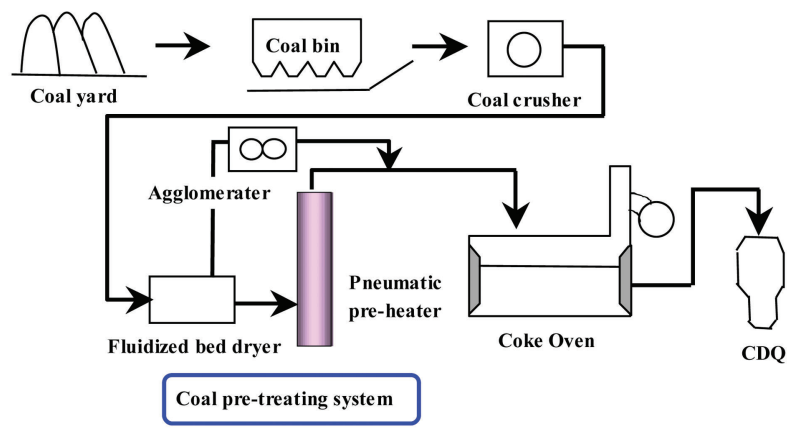

Fig. 14 Process flow of Oita No. 5 coke oven battery 
Table 3 Main specification of Oita No. 5 coke oven battery

\begin{tabular}{l|l|l}
\hline \multicolumn{2}{|c|}{ Equipment } & \multicolumn{1}{c}{ Specification (Capacity) } \\
\hline Coal & Fluidized bed dryer & 155 dry- $\mathrm{t} / \mathrm{h}$ \\
Pre-treating & Pneumatic pre-heater & 106 dry- $\mathrm{h} / \mathrm{h}$ \\
& Agglomerater & 34 dry-t/h $\times 2$ \\
\hline Coke oven & Coke oven chamber & 64 ovens, $6.7 \mathrm{mH} \times 0.45 \mathrm{~mW} \times 16.6 \mathrm{~mL}$ \\
\hline $\mathrm{CDQ}$ & $120 \mathrm{t} / \mathrm{h}$ \\
\hline
\end{tabular}

わが国の鉄鋼業におけるコークス製造部門における石 炭有効利用技術の開発の中で, SCOPE21 プロセスの開発 プロジェクトは，わが国のコークス製造技術の発展に向 けて, 各社が共通の問題意識を持ってその課題に取り組 み, 実を結んだ成果である。将来的に, わが国で開発さ れたSCOPE21プロセスによる新しいコークス炉が順次建 設され, 鉄鋼業の発展に対して貢献することが強く期待 されている。

\section{5. まとめ}

鉄鋼業に拈ける高炉操業にとって, コークスは重要な 還元材であり，他に代替できる炭素材料はない。近年，鉄 鋼の世界的な需要および生産の拡大により鉄鋼原料の需 給は逼迫し, その価格は高騰している。特に, 良質な原 料炭はその傾向が一層強くなっている。SCOPE21プロセ スは, 石炭資源の有効利用および地球温暖化防止対策 ( $\mathrm{CO}_{2}$ 削減) に直接的に貢献できる方法である。今後, わ が国の鉄鋼業の国際競争力の強化に大きく貢献するとと もに, 地球温暖化問題への解決にも大きく貢献すること が期待される。

コークス製造技術は，高温の還元雲囲気条件下で石炭 を乾留して，高炉用コークスを製造する技術である。わ が国では，石炭資源の特性を十分に検討するとともに，石 炭性状に適したプロセス開発が盛んに行われ，実機化さ れてきた。コークス製造技術の開発を通じて得られたこ れまでの成果が, 石炭利用技術の進歩に貢献することが 期待される。

今後は, さらに新しい切り口と最新技術を導入するこ とにより, 石炭資源の特性に応じた有効利用技術の研究 開発が飛躍的に発展することが望まれる。従来のコーク ス製造プロセスに比べて, 魅力のある新しいコークス製 造プロセスが永続的に研究開発され，世界に発信される ことが大いに期待されている。

\section{文 献: References}

1) Handbook for Iron and Steel Statistics, (JISF Ed.), 52, pp. 114-115(2012)：鉄鋼統計要覧, 日本鉄鋼連盟編, 52, pp. 114-115(2012)

2) J. Jpn. Inst. Energy, 87, 564(2008)

3) Wakuri, S.: Ferrum, 8, 371 (2003): 和栗眞次郎, ふえら
む, 8, 371(2003)

4) Nozawa, K.; Maki, T.; Shibata, K.; Goto, T.; Matsui, Y.: CAMP-ISIJ, 11, 833(1998)：野沢健太郎, 牧剛司, 柴田 耕一郎, 後藤哲也, 堀隆一, 松井良行, CAMP-ISIJ, 11, 833(1998)

5) Maruyama, T.; Maki, A.; Shimomura, A.; Okouchi, I; Mori, K.; Sato, M.: CAMP-ISIJ, 11, 834(1998) : 丸山太一, 牧 章, 下村昭夫, 大河内嚴, 森候寿, 佐藤道貴, CAMPISIJ, 11, 834 (1998)

6) Sato, M.; Murai, R.; Ariyama, T.; Maki, A.; Shimomura, A.; Mori, K.: Tetsu-to-Hagané, 84, 37-42 (1998)：佐藤道貴, 村井良太, 有山達郎, 牧章, 下村昭夫, 森候寿, 鉄と 鋼, 84, 37-42 (1998)

7) Japan. Institute of Energy Ed., Coke note, p. 24(2010) : 日本エネルギー学会編, コークス・ノート, p. 24 (2010)

8) Nishioka, K.: Taiyo-no-Kaseki Sekitan, (Agune), p. 200 (1990) : 西岡邦彦, 太陽の化石 石炭, (アグネ), p. 200(1990)

9） Kato. K.: J. Jpn. Inst. Energy, 86, 480-487 (2007) : 加藤健 次, J. Jpn. Inst. Energy, 86, 480-487 (2007)

10) Kimura, H.; Fujii, S.: Sekitan Kagaku to Kogyo (Sankyo Shuppan), pp. 24-42 (1984) : 木村英雄, 藤井修治, 石 炭 化学と工業 (三共出版), pp. 24-42(1984)

11) Sakawa, M.; Komkai, I.; Yamaguchi, K.: Coal and Coke, (ISIJ Ed.), pp. 68-79(2002) : 坂輪光弘, 古牧育男, 山 口一良，石炭・コークス，日本鉄鋼協会編，pp. 68-79 (2002)

12) Jo, H.: Nenryo Kyokai-shi, 26, 1-10(1947)：城博, 燃料協 会誌，26，1-10(1947)

13） Kato, K.: J. Jpn. Inst. Energy, 87, 344-352 (2008)：加藤健 次, J. Jpn. Inst. Energy, 87, 344-352(2008)

14) Mochida, I.: Clean Coal Technology, (Kogyo Chosakai), pp. 138-146(2008)：持田勲編著, 図解 クリーンコー ルテクノロジー(工業調査会), pp. 138-146(2008)

15) Wakuri, S.; Ohno, M.; Hosokawa, K.; Nakagawa, K.; Takanohashi, Y.; Ohnishi, T.; Kushioka, K.; Konno, Y.: 45th Ironmaking Conf., 303 (1996)

16) Nakashima, Y.; Mochizuki, S.; Ito, S.; Nakagawa, K.; Nishimoto, K.; Kobayashi, K.: 2nd International 
Cokemaking Congress, 518(1992)

17) Tanaka, S.; Okanishi, K.; Kikuchi, A.; Yamamura, Y.: 56th Ironmaking Conf., 56 (1997)

18) Kobayashi, K.; Yamaguchi, T:; Okuhara, T.: Tetsu-to-Hagané, 71, S841 (1985)：小林勝明，山口徳二，奥原捷晃，鉄 と鋼, 71, S841 (1985)

19) Nakashima, Y.; Yamamura, Y.: Tetsu-to-Hagané, 73, S796 (1987)：中嶋義明，山村雄一，鉄と鋼，73，S796 (1987)

20) Nishioka, K.: Tetsu-to-Hagané, 82, 353-360(1996) : 西岡邦 彦，鉄と鋼，82，353-360(1996)

21） Nishioka, K.: J. Jpn. Inst. Energy, 77, 899 (1996)：西岡邦 彦, J. Jpn. Inst. Energy, 77, 899 (1996)

22) Kato, K.: Recent Development and Future of Ironmaking technology, 61 (2003) : 加藤健次, 第179回西山記念講 座，製銑技術の最近の進歩と今後の展開，61(2003)

23) Nishioka, K.; Oshima, H.; Sugiyama, I.; Fujikawa, H.: Tetsuto-Hagané, 90, 614-619(2004)：西岡邦彦，大島弘信，杉 山勇夫，藤川秀樹，鉄と鋼，90，614-619(2004)

24) Kato, K.: Advanced Clean Coal Technologies in Japan,
(CMC Publishing), pp. 193-202(2009)：加藤健次，石 炭利用の最新技術と展望 (CMC出版), pp. 193-202 (2009)

25) Matsuura, M.; Sasaki, M.; Kato, K.; Nakashima, Y.: Tetsuto-Hagané, 90, 656-660 (2004)：松浦慎, 佐々木正樹, 加 藤健次，中嶋義明，鉄と鋼，90，656-660 (2004)

26) Nagai, K.; Suzuki, A.; Sunagawa, T.; Suyama, S.: Tetsu-toHagané, 90, 627-633(2004)：永井和範，鈴木淳，砂川辰 則，須山真一，鉄と鋼，90，627-633(2004)

27) Matsuda, Y.; Yokomizo, M.; Sasaki, M.; Matsuura, M.: Tetsuto-Hagané, 90, 648-655(2004)：松田雄市，横溝正彦, 佐々木正樹，松浦慎，鉄と鋼，90，648-655(2004)

28) Kubota, Y.; Arima, T.; Kato, K.; Matsuura, M.; Nakai, H.; Sasaki, M.; Sugiyama, I.: Tetsu-to-Hagané, 90, 686-693 (2004)：窪田征弘, 有馬孝, 加藤健次, 松浦慎, 中居 裕貴，佐々木正樹，杉山勇夫，鉄と鋼，90，686-693 (2004)

29) NIKKEI BUSINESS DAILY, 2013.6.19：日経産業新聞, 2013年 6 月 19 日 